\title{
Salt stress in apple seedlings was mitigated by $n$-propyl dihydrojasmonate, a synthetic analog of jasmonic acid
}

\author{
L. Wang ${ }^{1}$, S. Wang ${ }^{1}$, H. Tomiyama ${ }^{1}$, P. Opio ${ }^{1}$, H. Ohara ${ }^{2}$, K. Ohkawa ${ }^{1}$, T. Saito ${ }^{1}$ and S. Kondo ${ }^{1}$ \\ ${ }^{1}$ Graduate School of Horticulture, Chiba University, Matsudo, Japan \\ ${ }^{2}$ Center for Environment, Health and Field Sciences, Chiba University, Kashiwa, Japan
}

\section{Summary}

The effects of $n$-propyl dihydrojasmonate (PDJ) application, which is a synthetic analog of jasmonic acid (JA) against sodium chloride $(\mathrm{NaCl})$ stress in apple seedlings, were examined. The malondialdehyde (MDA) and proline concentrations, endogenous JA and abscisic acid (ABA) concentrations, antioxidant activities, $\mathrm{Na}^{+}$and $\mathrm{K}^{+}$concentrations, along with 9-cis-epoxycarotenoid deoxygenase 1 (MdNCED1), ABA 8'-hydroxylase 1 (MdCYP707A1), allene oxide synthase 1 (MdAOS1), jasmonate resistant (MdJAR), jasmonate ZIM-domain 2 (MdJAZ2), D1-pyrroline-5-carboxylate synthetase (MdP5CS), ornithine aminotransferase 1 (MdOAT1), proline dehydrogenase (MdPDH), salt overly sensitive 1 (MdSOS1) and $\mathrm{Na}^{+} / \mathrm{H}^{+}$exchanger 1 (MdNHX1) gene expressions in the leaves were analyzed. NaCl treatment without PDJ application (PDJ $\mathrm{NaCl}^{+}$) significantly decreased chlorophyll concentrations and superoxide (SOD), peroxidase (POD) and catalase (CAT) activities, but increased the ion leakage, MDA, proline, and $\mathrm{Na}^{+}$concentrations, as well as the hydrogen peroxide $\left(\mathrm{H}_{2} \mathrm{O}_{2}\right)$ and endogenous JA and ABA concentrations in the leaves. Foliar application of PDJ before $\mathrm{NaCl}$ treatment $\left(\mathrm{PDJ}{ }^{+} \mathrm{NaCl}^{+}\right)$decreased $\mathrm{Na}^{+}$ concentrations, ion leakage, MDA, proline accumulation and $\mathrm{H}_{2} \mathrm{O}_{2}$ generation, but increased $\mathrm{K}^{+}$concentrations, antioxidant capacity, and chlorophyll concentrations in the leaves. In the $\mathrm{PDJ}^{+} \mathrm{NaCl}^{-}$group, although the JA and ABA concentrations and MdAOS1, MdJAR, and MdNCED1 gene expressions were increased, the MdJAZ2 and MdCYP707A1 gene expressions were decreased. In addition, the $\mathrm{PDJ}^{+} \mathrm{NaCl}^{+}$group showed higher MdPDH, MdSOS1, and MdNHX1 gene expressions and lower MdP5CS gene expressions than the $\mathrm{PDJ}^{-\mathrm{NaCl}^{+}}$group at $\mathbf{7}$ and $\mathbf{1 0}$ days after treatment. The present data suggested that PDJ application could induce rapidly endogenous JA and $\mathrm{ABA}$, enhance SOD, POD, and CAT activities, decrease the $\mathrm{Na}^{+}$uptake, and mitigate $\mathrm{NaCl}$ stress.

Keywords

abscisic acid, antioxidant activity, jasmonic acid, Malus domestica, $\mathrm{NaCl}$ stress, proline

\section{Introduction}

Sodium chloride $(\mathrm{NaCl})$ in soil causes ion toxicity, the formation of reactive oxygen species (ROS), membrane dysfunction, oxidative damage, and the attenuation of multiple metabolic activities (Annunziata et al., 2017). Exposure to

\section{Significance of this study}

What is already known on this subject?

- PDJ application can enhance chilling tolerance.

What are the new findings?

- PDJ application mitigates $\mathrm{NaCl}$ stress by inducing endogenous JA and ABA accumulation, enhancing antioxidant activities, and reducing $\mathrm{Na}^{+}$uptake in apple seedlings.

What is the expected impact on horticulture?

- PDJ mitigates $\mathrm{NaCl}$ stress in fruit trees and results in stable yield and fruit quality.

an unfavorable abiotic environment leads plants to develop strategies to respond appropriately. These strategies include the alteration of phytohormones such as jasmonic acid (JA) and abscisic acid (ABA) and amino acids such as proline levels (Figure 1). JA can reinforce stress resistance in plants exposed to $\mathrm{NaCl}$ by enhancing the activities of antioxidant enzymes and triggering the expression of stress response genes (Ruan et al., 2019). Pedranzani et al. (2003) showed that salt-tolerant tomato (Solanum lycopersicum) showed higher levels of JA concentrations and AOS gene expressions. The JA signaling mechanism against abiotic stress involves the activation of JA by the JAR gene, which conjugates JA and isoleucine to jasmonoyl-L-isoleucine (JA-Ile), and ultimately activates the downstream responses via the degradation of jasmonate ZIM-domain (JAZ) repressor proteins (Figure 1A) (Ruan et al., 2019).

Plants accumulate ABA through the functions of two key enzymes, 9-cis-epoxycarotenoid deoxygenase (NCED) and ABA 8'-hydroxylase (CYP707A) (Waśkiewicz et al., 2013) (Figure 1B). Over-expression of the OSNCED5 gene enhanced salt tolerance by controlling ABA biosynthesis and genes related to abiotic stress in rice (Oryza sativa L.) (Huang et al., 2019). Sales et al. (2017) found that the inhibition of CYP707A1 attenuated the catabolism of ABA and increased endogenous $\mathrm{ABA}$ concentrations under $\mathrm{NaCl}$ stress and decreased $\mathrm{Na}^{+}$intake and mitigated salinity damage in apple seedlings. Generally, crosstalk exists between ABA and JA with regard to their signaling behavior (Yang et al., 2019). De Ollas et al. (2013) found that JA transient accumulation was needed for the ABA response to salt tolerance in citrus (Citrus reticulate Blanco).

Various antioxidant enzymes such as superoxide dismutase (SOD), catalase (CAT) and peroxidase (POD) have been induced against salt stress (Ahmad et al., 2016). As a free radical scavenger, proline is synthesized by the enzyme 


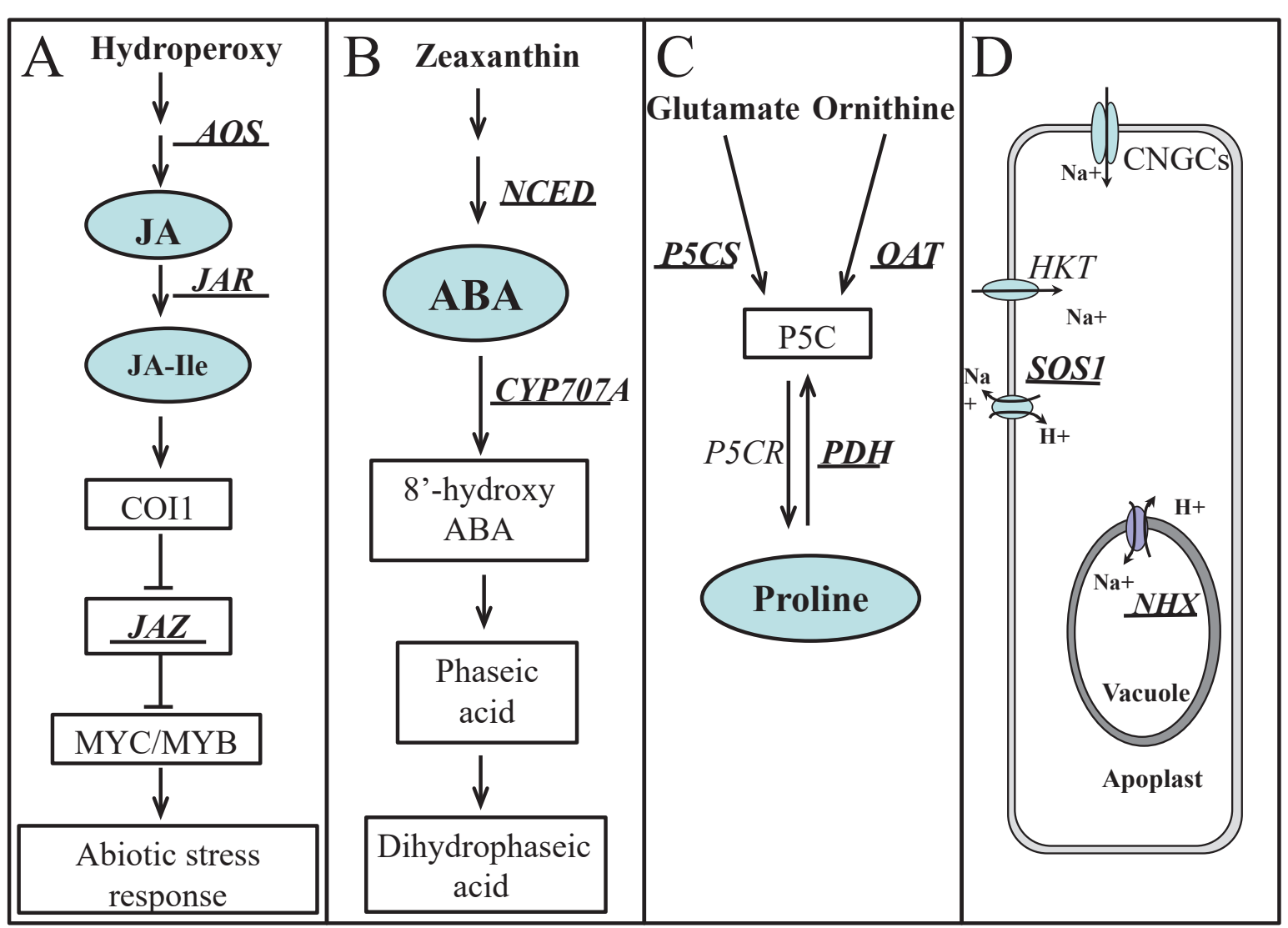

FigURE 1. A summary of a schematic representation of the biosynthesis and degradation of JA, ABA, and proline (A, B, C) and the $\mathrm{Na}^{+}$ion transport in plant cells (D). The genes analyzed in our study are underlined. (A) JA-related genes: AOS, allene oxide synthase; JAR, jasmonate resistant; JAZ, jasmonate ZIM-domain; (B) ABA-related genes: NCED, 9-cis-epoxycarotenoid deoxygenase; CYP707A, ABA 8'-hydroxylase; (C) proline-related genes: P5CS, $\triangle^{1}$-pyrroline-5-carboxylate synthetase; OAT, ornithine aminotransferase; $P 5 C R, \triangle^{1}$-pyrroline-5-carboxylate reductase; $P D H$, proline dehydrogenase; (D) $\mathrm{Na}^{+}$ion-transport-related genes: SOS1, salt overly sensitive 1; $\mathrm{NHX}, \mathrm{Na}^{+} / \mathrm{H}^{+}$exchanger; $\mathrm{HKT}, \mathrm{Na}^{+}$and/or $\mathrm{K}^{+}$permeable transporter.

$\Delta$ 1-pyrroline-5-carboxylate synthatase (P5CS) and ornithine-delta-aminotransferase (OAT), and degraded through oxidation by proline dehydrogenase (PDH) (Cao et al., 2020; Figure 1C). It has been shown that proline accumulation under salt stress in plant tissues is attributed to the high expression of the P5CS gene and decreased expression of the $P D H$ gene (Cao et al., 2020). This resulted in protection against $\mathrm{NaCl}$-induced ROS and lipid peroxidation through the increase of antioxidant enzyme activities (Reddy et al., 2015). ABA induced proline production in salt-stressed plants by activating P5CS gene expression (Guan et al., 2019). ABA regulates the intracellular $\mathrm{Na}^{+}$dynamic balance via inducing the expression of the salt overly sensitive 1 (AtSOS1) and $\mathrm{Na}^{+} / \mathrm{H}^{+}$ exchanger 1 (AtNHX1) genes in Arabidopsis thaliana (Figure 1D). Both genes encode the plasma membrane $\mathrm{Na}^{+} / \mathrm{H}^{+}$transporter and $\mathrm{Na}^{+} / \mathrm{H}^{+}$exchanger protein, functioning as an $\mathrm{Na}^{+}$ efflux carrier from the cell and in $\mathrm{Na}^{+}$compartmentalization in vacuoles (Yamaguchi et al., 2013).

A synthetic analog of JA, $n$-propyl dihydrojasmonate (PDJ), has been widely used in Japan for the promotion of apple coloration (Kondo et al., 2000). PDJ could inhibit Botrytis cinerea pathogen infection in apples (Suktawee et al., 2019). PDJ treatment also improved chilling tolerance in apple fruits through the induction of scavenging activity against reactive oxygen (Kondo, 2009). Therefore, PDJ application may mitigate biotic and abiotic stresses, including salinity.

In the present study, the endogenous JA and ABA and proline concentrations, SOD, POD, CAT, and ascorbate peroxidase (APX) antioxidant activities, $\mathrm{Na}^{+}$and $\mathrm{K}^{+}$concentrations, and their respective gene expressions were examined to clarify whether PDJ can mitigate $\mathrm{NaCl}$ stress in apple seedlings.

\section{Materials and methods}

\section{Plant materials and treatment}

Ninety-day-old 'Tsugaru' apple seedlings [Malus sylvestris (L.) Mill. var. domestica (Borkh.) Mansf.] were used. The germinated apple seeds were sown in plastic trays $(26 \times 52$ $\times 6 \mathrm{~cm}$ ) with a capacity of 72 seeds per tray with a spacing of $4 \times 4 \mathrm{~cm}$, containing moist vermiculite as a substrate. The trays were set under the greenhouse for growth; a half liter of water was added in the bottom of each tray every day to keep it moist, and $0.2 \%(\mathrm{v} / \mathrm{v})$ Hyponex ${ }^{\circledR}$ solution was applied as a nutrient (Hyponex Japan Co., Osaka, Japan). The seedlings were grown under natural light conditions with an average daytime temperature range in the greenhouse of 25 to $30^{\circ} \mathrm{C}$, and a range of 15 to $20^{\circ} \mathrm{C}$ at night.

Treatment consisted of an application of $0.8 \mathrm{mM}$ of PDJ solution containing $0.5 \%$ Approach $\mathrm{BI}^{\circledR}$ (Maruwa Biochemical Co., Tokyo, Japan) on both sides of the leaves. After $24 \mathrm{~h}, 100 \mathrm{mM} \mathrm{NaCl}$ was applied to seedlings by dipping into $1 \mathrm{~L} \mathrm{NaCl}$ solutions per tray. The apple seedlings were divided into four groups as follows: (1) a group without any treatment (untreated control); (2) a group treated 
with $0.8 \mathrm{mM}$ of PDJ solution, but without $\mathrm{NaCl}\left(\mathrm{PDJ}^{+} \mathrm{NaCl}\right)^{-}$; (3) a group treated with $100 \mathrm{mM} \mathrm{NaCl}$ solution, without PDJ application (PDJ $\mathrm{NaCl}^{+}$); and (4) a group administered a combination of $100 \mathrm{mM} \mathrm{NaCl}$ and $\mathrm{PDJ}\left(\mathrm{PDJ}^{+} \mathrm{NaCl}^{+}\right)$. The concentrations of PDJ and $\mathrm{NaCl}$ were based on a previous study by Sales et al. (2017). A total of 240 seedlings were sampled from each group, divided into three replications, and healthy fresh leaves were collected at 1, 4, 7, and 10 days after the beginning of the $\mathrm{NaCl}$ treatment, frozen with liquid nitrogen, and kept at $-80^{\circ} \mathrm{C}$ until further analysis.

\section{Determination of ion leakage and lipid peroxidation}

Ion leakage was determined according to Jambunathan (2010). The fourth leaf from the tip of each seedling (six replications per each treatment) was sampled, and ion leakage was determined using an electrical conductivity meter (LAQUAtwin-pH-22, Horiba, Japan). The relative ion leakage was expressed as a percentage of conductivity before and after the boiling of leaves in respective aqueous extracts. The amount of malondialdehyde (MDA) was measured according to Heath and Packer (1968). MDA was determined spectrophotometrically at $\mathrm{OD}_{450}, \mathrm{OD}_{532}$, and $\mathrm{OD}_{600}$ using the UV-VIS spectrophotometer (2J1-0010, Hitachi, Japan).

\section{Measurement of hydrogen peroxide $\left(\mathrm{H}_{2} \mathrm{O}_{2}\right)$, proline concentrations, and antioxidative enzyme activity}

The concentrations of $\mathrm{H}_{2} \mathrm{O}_{2}$ in fresh leaves $(0.5 \mathrm{~g}$, three replications) were measured according to the method of Shi et al. (2005). The absorbance was at $390 \mathrm{~nm}$, and the final concentration was calculated according to the standard curve derived from different concentrations of $\mathrm{H}_{2} \mathrm{O}_{2}$. The proline concentrations were assayed based on the method of Sales et al. (2017). The fresh leaf tissues $(0.5 \mathrm{~g}$, three replications) were homogenized with $10 \mathrm{~mL}$ sulfosalicylic acid $3 \%$ $(\mathrm{w} / \mathrm{v})$ and then centrifuged at $15,000 \mathrm{~g}$ for $10 \mathrm{~min}$. After reaction with ninhydrin solution, the compound was measured at $520 \mathrm{~nm}$ by a spectrophotometer (U-2910; Hitachi, Tokyo, Japan). A standard curve was obtained using L-proline. For antioxidant enzyme analysis, the leaf tissues (three replications of $0.5 \mathrm{~g}$ ) were homogenized with $15 \mathrm{~mL}$ phosphate buffer (50 mM, pH 7.8) containing $0.5 \mathrm{mM}$ EDTA and $2 \%(\mathrm{w} / \mathrm{v})$ polyvinylpyrrolidone and centrifuged at $15,000 \mathrm{~g}$ for $15 \mathrm{~min}$. The antioxidant enzyme activities of SOD, POD, CAT, and APX were measured according to the method of He et al. (2014).

Determination of chlorophyll, $\mathrm{Na}^{+}$and $\mathrm{K}^{+}$concentrations

After the extraction of chlorophyll in the leaves using $\mathrm{N}$, $\mathrm{N}$-dimethylformamide, the chlorophyll concentration was measured at absorbances of 663 and $645 \mathrm{~nm}$ using a spectrophotometer (U-2910; Hitachi, Tokyo, Japan). The chlorophyll $a(\mathrm{Chl} a)$, chlorophyll $b(\mathrm{Chl} b)$, and total chlorophyll concentrations were calculated according to Burton et al. (1986). $\mathrm{The} \mathrm{Na}^{+}$and $\mathrm{K}^{+}$concentrations in the leaves were determined according to Sales et al. (2017). The leaf samples (0.5 g dry weight, three replications) were mixed with $15 \mathrm{~mL}$ nitric acid, then converted to ashes at $450^{\circ} \mathrm{C}$ and finally ground into powder. The residues were dissolved in $0.1 \mathrm{~N}$ hydrochloric acid and filtered. The solutions were analyzed by multitype ICP emission spectrometers (ICPE-9000; ICP-AES Multitype ICP Emission Spectrometer, Shimadzu, Japan).

\section{Analysis of JA and ABA}

JA in the leaves was analyzed according to Suktawee et al. (2019). Leaf samples (1 g FW, three replications) were homogenized in $10 \mathrm{~mL}$ saturated $\mathrm{NaCl}$ solution, $20 \mathrm{~mL}$ diethyl ether containing $0.005 \%$ butylated hydroxytoluene (BHT) and $500 \mu \mathrm{L}$ of $1 \mathrm{M}$ citric acid, and $100 \mu \mathrm{L}\left[( \pm)-2-\left(2,3-{ }^{2} \mathrm{H}_{2}\right)\right] \mathrm{A}$ (100 $\left.\left.\mathrm{mg} \mathrm{L}^{-1}\right)\right]$ as an internal standard. The final extract was dissolved with methanol and analyzed using gas chromatography/mass spectrometry-selective ion monitoring (GCMS-SIM) (QP 5000; Shimadzu, $25 \mathrm{~m} \times 0.25 \mathrm{~mm}$ I.D. column) as described by Kondo et al. (2009). The ABA was extracted using the method described by Sales et al. (2017). Leaf samples (1 $\mathrm{g} \mathrm{FW,} \mathrm{three} \mathrm{replications)} \mathrm{were} \mathrm{homogenized} \mathrm{with}$ $20 \mathrm{~mL}$ cold $80 \%$ (v/v) methanol with $100 \mathrm{mg} \mathrm{L}^{-1}$ BHT and $0.5 \mathrm{~g}$ polyvinylpolypyrrolidone as a stabilizer with $0.2 \mu \mathrm{g}$ ABA- $d_{6}$ as an internal standard. The extract was purified with high performance liquid chromatography (flow rate, $1.5 \mathrm{~mL}$ $\mathrm{min}^{-1}$; detection at $254 \mathrm{~nm}$; ODS-Mightysil RP-18 column, $250 \mathrm{~mm} \times 4.6 \mathrm{~mm}$ i.d.) and finally measured with GC-MS-SIM (QP5000; Shimadzu, Kyoto, Japan).

\section{Total RNA isolation, cDNA synthesis and quantitative reverse transcription polymerase chain reaction (qRT-PCR) analysis}

Total RNA was extracted using cetyltrimethylammonium bromide as reported by Kondo et al. (2012). The first-strand cDNA was synthesized from $1 \mu \mathrm{g}$ of total RNA according to the instruction manual of ReverTra Ace ${ }^{\circledR}$ qPCR RT Master Mix (Toyobo, Osaka, Japan). qRT-PCR was performed on a StepOnePlus ${ }^{\mathrm{TM}}$ system (Applied Biosystems, U.S.A.) using the Thunderbird ${ }^{\mathrm{TM}}$ SYBR $^{\circledR}$ qPCR Mix (Toyobo, Osaka, Japan). The primers except for the MdUbiquitin-11 gene were designed using Beacon Designer 7 (Premier Biosoft Int.) software (Supplemental Table 1). The MdUbiquitin-11 gene was used as an internal control gene. The results were calculated using the $2^{-\Delta \Delta \mathrm{CT}}$ method (Yu et al., 2007). Three biological replicates were performed for each set of treatment.

\section{Statistical analysis}

All data were statistically analyzed with SPSS statistics software (IBM SPSS statistics 20, IBM Corp., Armonk, NY) and means separated using Duncan's multiple range test at the $\mathrm{P} \leq 0.05$ level.

\section{Results}

Chlorophyll, MDA, ion leakage and $\mathrm{H}_{2} \mathrm{O}_{2}$ concentrations

At 10 days after treatment (DAT), the concentrations of Chl $a$, Chl $b$, and total chlorophyll were lowest in the PDJ$\mathrm{NaCl}^{+}$group compared to the other groups (Figure 2a). The $\mathrm{Chl} a / \mathrm{Chl} b$ ratio was highest in the $\mathrm{PDJ}-\mathrm{NaCl}^{+}$group, followed by the $\mathrm{PDJ}^{+} \mathrm{NaCl}^{+}$and $\mathrm{PDJ}{ }^{+} \mathrm{NaCl}^{-}$groups, and the untreated control group was the lowest.

The ion leakage and MDA and $\mathrm{H}_{2} \mathrm{O}_{2}$ concentrations in the leaves exhibited a similar tendency. These increased in the $\mathrm{PDJ}-\mathrm{NaCl}^{+}$and $\mathrm{PDJ}{ }^{+} \mathrm{NaCl}^{+}$groups through $\mathrm{NaCl}$ treatment (Figures $2 \mathrm{~b}-\mathrm{d}$ ). The $\mathrm{PDJ}^{+} \mathrm{NaCl}^{+}$group showed lower concentrations compared to the PDJ $\mathrm{NaCl}^{+}$group at 7 and $10 \mathrm{DAT}$. Ion leakage and MDA production at 7 and 10 DAT were not significantly different between the $\mathrm{PDJ}^{+} \mathrm{NaCl}^{-}$group and the untreated controls. The $\mathrm{PDJ}^{+} \mathrm{NaCl}^{-}$group showed increased $\mathrm{H}_{2} \mathrm{O}_{2}$ concentrations compared to the untreated control at 1 and 4 DAT.

\section{Endogenous JA concentrations and expressions of JA-related genes}

The endogenous JA concentrations in the PDJ $\mathrm{NaCl}^{+}$and $\mathrm{PDJ}^{+} \mathrm{NaCl}^{+}$groups were significantly higher from 4 to $10 \mathrm{DAT}$ compared to the untreated controls (Figure 3a). JA in the 


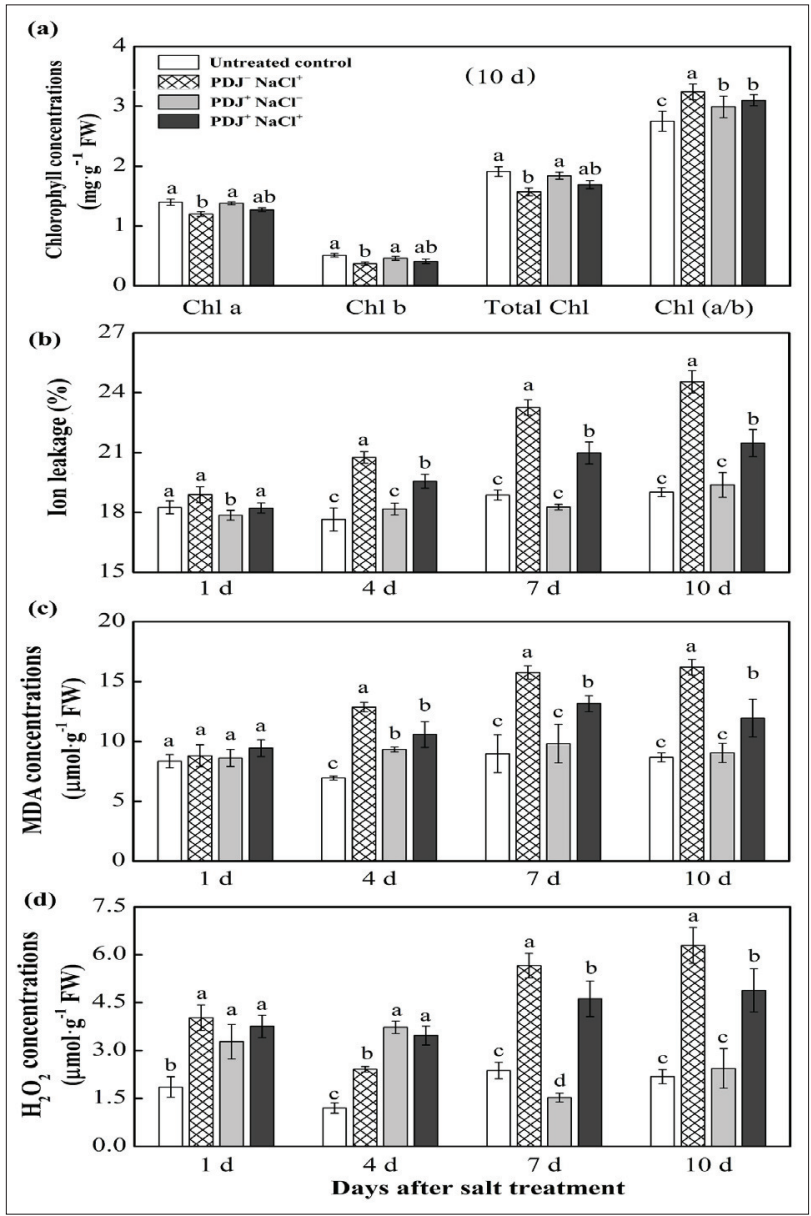

Figure 2. Changes of Chl $a$, $\mathrm{Chl} b$, and total Chl (a), ion leakage (b), MDA (c), and $\mathrm{H}_{2} \mathrm{O}_{2}$ (d) concentrations. Chlorophyll concentrations were obtained only at 10 DAT in this study. The data represent the average value \pm SE of six replications for the ion leakage and of three replications for the other indexes. Different letters indicate significant differences as determined by Duncan's multiple range test at $\mathrm{P} \leq 0.05$.

$\mathrm{PDJ}^{+} \mathrm{NaCl}^{+}$group was 1.8 -fold that in the $\mathrm{PDJ}-\mathrm{NaCl}^{+}$group at 1 DAT. The JA concentrations in the $\mathrm{PDJ}^{+} \mathrm{NaCl}^{-}$group increased at 1 and 4 DAT. Both the allene oxide synthase 1 (MdAOS1) and jasmonate resistant (MdJAR) genes were up-regulated by $\mathrm{NaCl}$ treatment compared with the untreated control group at 4, 7, and 10 DAT (Figure $3 \mathrm{~b}, \mathrm{c}$ ). Compared to the PDJ $\mathrm{NaCl}^{+}$group, the MdAOS1 and MdJAR gene expressions in the $\mathrm{PDJ}^{+} \mathrm{NaCl}^{+}$group showed higher levels at 7 and $10 \mathrm{DAT}$, respectively. On the other hand, the expressions of the jasmonate ZIM-domain 2 (MdJAZ2) gene in the $\mathrm{PDJ}^{-} \mathrm{NaCl}^{+}$group were significantly lower than those in the untreated control (Figure 3d). In the $\mathrm{PDJ}^{+} \mathrm{NaCl}^{+}$group, the expressions of the MdJAZ2 gene were lower than that in the $\mathrm{PDJ}-\mathrm{NaCl}^{+}$group at 1 and 4 DAT.

\section{Endogenous ABA concentrations and expressions of ABA-related genes}

$\mathrm{NaCl}$ treatment $\left(\mathrm{PDJ}{ }^{+} \mathrm{NaCl}^{+}\right.$and $\left.\mathrm{PDJ}-\mathrm{NaCl}^{+}\right)$significantly increased the ABA concentrations compared to other treatments at 4, 7, and 10 DAT (Figure 4a). The ABA concentrations in the $\mathrm{PDJ}^{+} \mathrm{NaCl}^{+}$treatment were higher than those in the PDJ $-\mathrm{NaCl}^{+}$group at 1 DAT but lower at 7 and 10 DAT. The ABA concentrations in the $\mathrm{PDJ}^{+} \mathrm{NaCl}^{-}$group were increased at 1 DAT but significantly declined at 7 and 10 DAT, compared to the PDJ- $\mathrm{NaCl}^{+}$group. The 9-cis-epoxycarotenoid deoxygen- ase 1 (MdNCED1) gene expressions in both the $\mathrm{PDJ}^{+} \mathrm{NaCl}^{+}$and PDJ $\mathrm{NaCl}^{+}$groups were up-regulated at 7 DAT (Figure $4 \mathrm{~b}$ ). The MdNCED1 gene expressions in the $\mathrm{PDJ}-\mathrm{NaCl}^{+}$group were highest compared to the other treatments at 10 DAT. The expression of the ABA 8'-hydroxylase 1 (MdCYP707A1) gene in the $\mathrm{PDJ}^{+} \mathrm{NaCl}^{-}$and $\mathrm{PDJ}^{+} \mathrm{NaCl}^{+}$groups showed a similar tendency as the MdNCED1 gene (Figure 4c).

\section{Antioxidant enzyme activities}

The SOD, CAT, and POD enzyme activities in the PDJ $\mathrm{NaCl}^{+}$group increased at 4 DAT but declined significantly at 10 DAT compared to the untreated control group (Figure $5 a-c)$. Foliar application of PDJ before the $\mathrm{NaCl}$ treatment (PDJ ${ }^{+} \mathrm{NaCl}^{+}$group) increased the antioxidant enzyme activities of SOD, CAT, POD, and APX compared to those of the PDJ $\mathrm{NaCl}^{+}$group at 7 DAT (Figure 5).

\section{Proline concentrations and expressions of proline- related genes}

The proline concentrations in the $\mathrm{PDJ}^{-} \mathrm{NaCl}^{+}$group significantly increased at 4, 7, and 10 DAT and followed by the $\mathrm{PDJ}^{+} \mathrm{NaCl}^{+}$group (Figure 6a). In general, the expressions of both the $\Delta 1$-pyrroline-5-carboxylate synthetase (MdP5CS) and ornithine aminotransferase 1 (MdOAT1) genes were significantly upregulated in the $\mathrm{PDJ}{ }^{+} \mathrm{NaCl}^{+}$and $\mathrm{PDJ}-\mathrm{NaCl}^{+}$groups compared to the untreated group at 4 to 10 DAT (Figure 6b, c). In contrast, the proline dehydrogenase (MdPDH) gene expression was downregulated in the PDJ $\mathrm{NaCl}^{+}$group (Figure $6 \mathrm{~d}$ ).

\section{$\mathrm{Na}^{+}$and $\mathrm{K}^{+}$concentrations and expressions of ion- transport-related genes}

The $\mathrm{Na}^{+}$concentrations in the $\mathrm{PDJ}{ }^{-} \mathrm{NaCl}^{+}$and $\mathrm{PDJ}^{+} \mathrm{NaCl}^{+}$ groups increased by 6.8 - and 2.5 -fold, respectively, compared to those in the untreated control group at 10 DAT (Figure 7a). The $\mathrm{PDJ}^{+} \mathrm{NaCl}^{-}$treatment did not influence the $\mathrm{Na}^{+}$concentrations compared to the untreated control, but it enhanced the $\mathrm{K}^{+}$levels at 7 and $10 \mathrm{DAT}$. The $\mathrm{K}^{+}$concentration in the $\mathrm{PDJ}^{+} \mathrm{NaCl}^{+}$group was highest, followed by those in the $\mathrm{PDJ}^{+} \mathrm{NaCl}^{-}$and $\mathrm{PDJ}-\mathrm{NaCl}^{+}$groups, and the untreated control group was lowest at 10 DAT. The highest $\mathrm{K}^{+} / \mathrm{Na}^{+}$ratio was the $\mathrm{PDJ}^{+} \mathrm{NaCl}^{-}$group, and the lowest was the $\mathrm{PDJ}-\mathrm{NaCl}^{+}$group. The expressions of both the salt overly sensitive 1 (MdSOS1) and $\mathrm{Na}^{+} / \mathrm{H}^{+}$exchanger 1 (MdNHX1) genes in the PDJ $\mathrm{NaCl}^{+}$ group increased at 4 DAT (Figure $7 \mathrm{~b}, \mathrm{c}$ ). The expressions of the MdSOS1 and MdNHX1 genes in the $\mathrm{PDJ}^{+} \mathrm{NaCl}^{+}$group were increased significantly compared to the other treatments at 7 and 10 DAT.

\section{Discussion}

In our study, a decrease in chlorophyll concentrations was observed in the $\mathrm{PDJ}-\mathrm{NaCl}^{+}$group, but there was no significant difference in the $\mathrm{PDJ}^{+} \mathrm{NaCl}^{+}$group, when compared with the control group. Rezai et al. (2013) found that MeJA application inhibited the degradation of chlorophyll in pepper (Capsicum annuum L.) under $\mathrm{NaCl}$ stress. During the process of chlorophyll degradation, $\mathrm{Chl} b$ is first converted to $\mathrm{Chl} a$, then degraded by chlorophyllase (Fang et al., 1998). This process may explain the increased ratio of $\mathrm{Chl} a / \mathrm{Chl} b$ and the decrease in the total chlorophyll concentrations in NaCl-treated leaves. Membrane lipids are considered to be significantly vulnerable to the salinity, and $\mathrm{NaCl}$-induced stress generates ROS, disrupting lipid membrane integrity and ion homeostasis (Reddy et al., 2015). Our study revealed that MDA, the final product of lipid peroxidation, and the ion leakage rate were significantly inhibited in the $\mathrm{PDJ}^{+} \mathrm{NaCl}^{+}$plants. Qiu et 


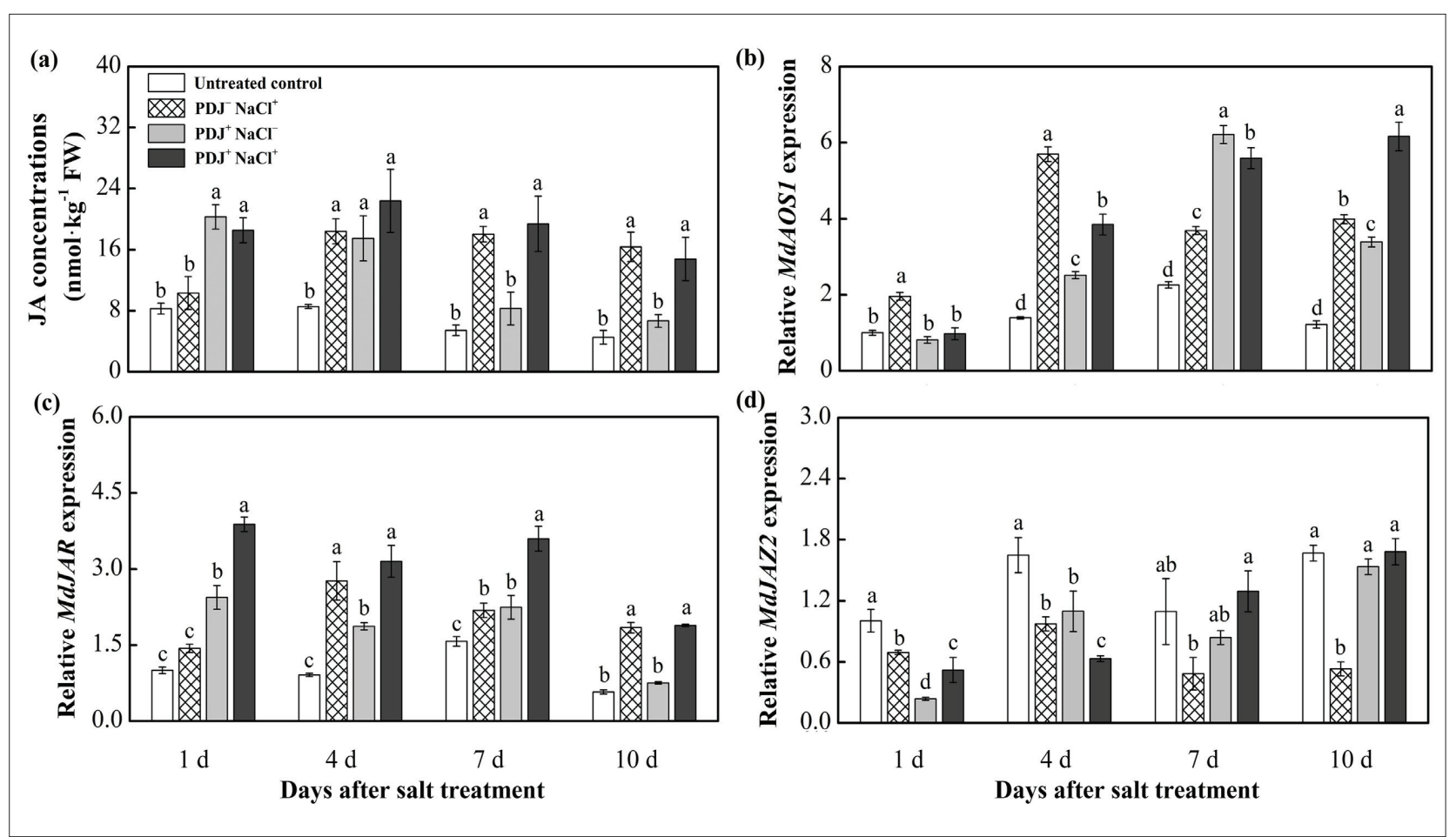

FigurE 3. Endogenous JA concentrations (a) and gene expressions of MdAOS1 (b), MdJAR (c), and MdJAZ2 (d). The data represent the average value \pm SE $(n=3)$. The MdAOS1, MdJAR, and MdJAZ2 were plotted compared to the control (Ubiquitin gene) expression. Different letters indicate significant differences as determined by Duncan's multiple range test at $\mathrm{P} \leq 0.05$.

al. (2014) reported that exogenous JA treatment ameliorated $\mathrm{NaCl}$ injury in wheat (Triticum aestivum L.) by decreasing the concentrations of MDA and $\mathrm{H}_{2} \mathrm{O}_{2}$ and the ion leakage rate. Meanwhile, at 7 DAT, the APX enzyme activity in the PDJ'Na$\mathrm{Cl}^{+}$group was higher than that in the PDJ- $\mathrm{NaCl}^{+}$group. These results suggested that the $\mathrm{PDJ}{ }^{+} \mathrm{NaCl}^{+}$treatment retarded the MDA production and ion leakage. Therefore, PDJ may mitigate membrane injury caused by $\mathrm{NaCl}$ stress.

It has been shown that ABA induced stomatal closure and up-regulated the expression of stress-related genes to increase salt tolerance (Waśkiewicz et al., 2013). Our results showed that the ABA concentrations and MdNCED1 gene expression were increased in the $\mathrm{PDJ}^{+} \mathrm{NaCl}^{+}$group. This was consistent with Kim et al. (2009), who found that JA application induced the increase of endogenous ABA concentrations quickly under $\mathrm{NaCl}$ stress and stronger salt tolerance in chard plant (Beta vulgaris L.). Huang et al. (2019) also reported that OSNCED5 transgenic plants presented stronger salt tolerance than wild-type plants owing to higher endogenous ABA concentrations. The JA concentrations in our study continually accumulated in the $\mathrm{PDJ}{ }^{+} \mathrm{NaCl}^{+}$group, as did the MdAOS1 gene expression. Pedranzani et al. (2003) also showed that salt-tolerant tomato showed higher levels of JA concentrations and $A O S$ gene expressions. The accumulation of endogenous JA could activate the expression of the JAR gene and enhance the conversion of JA to JA-Ile, resulting in the induction of the proteolysis of JAZ (Ruan et al., 2019). The higher expression of the MdJAZ2 gene in the $\mathrm{PDJ}^{+} \mathrm{NaCl}^{+}$group implied the higher accumulation of JA-Ile, whose function is in activating JA signaling pathways directly. Liu et al. (2019) reported that overexpression of the PnJAZ1 gene confers salinity tolerance in moss (Pohlia nutans) via crosstalk with the ABA signaling pathway. De Ollas et al. (2013) showed that both JA and ABA accumulated in salt-stressed plants. Thus, it is reasonable to presume that the application of PDJ initiated

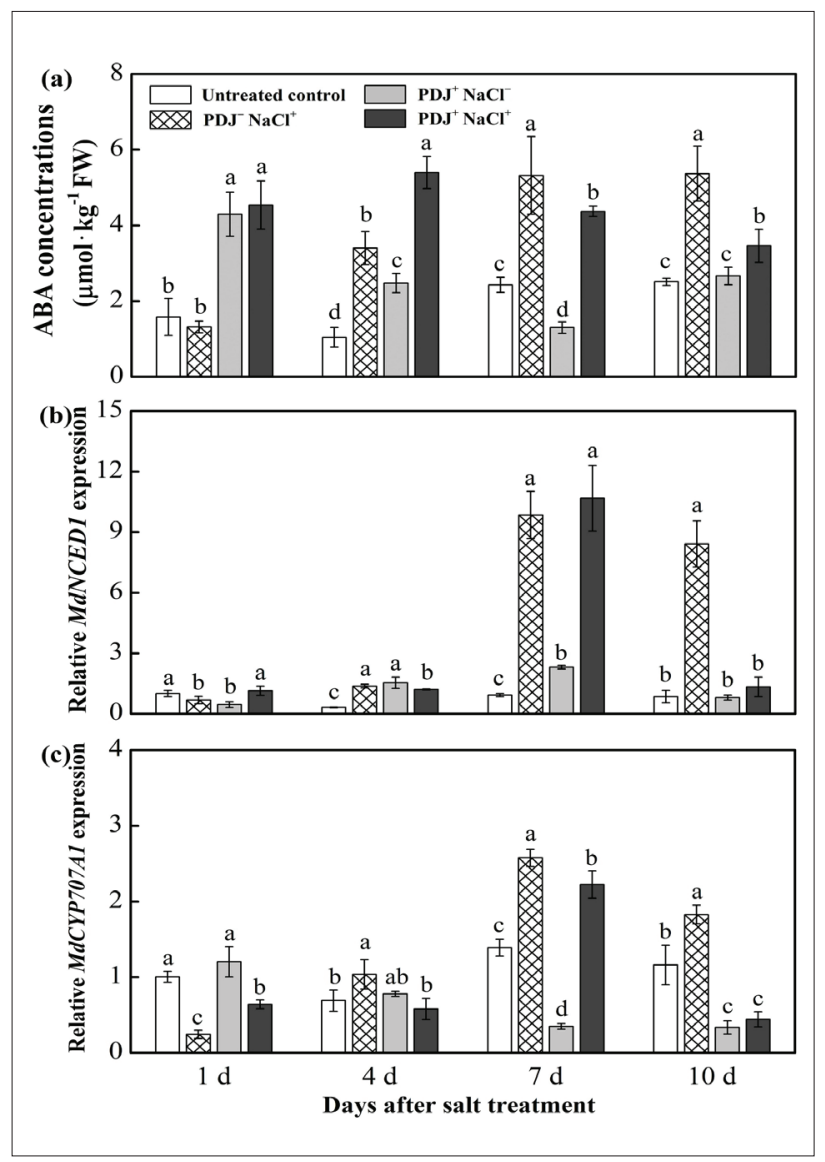

Figure 4. Endogenous ABA concentrations (a) and gene expressions of MdNCED1 (b) and MdCYP707A1 (c). The data represent the average value \pm SE $(n=3)$. Different letters indicate significant differences as determined by Duncan's multiple range test at $\mathrm{P} \leq 0.05$. 

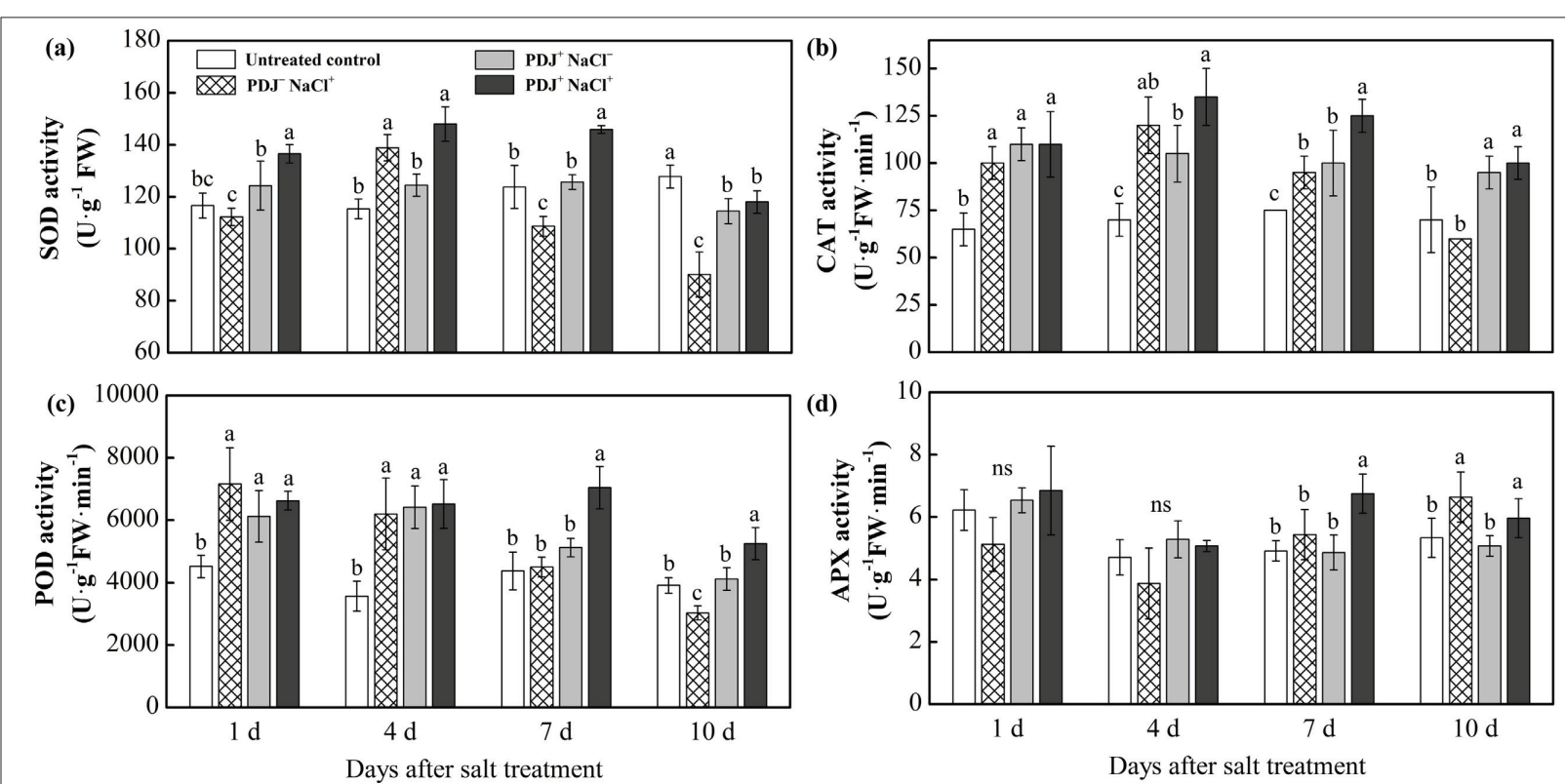

FIGURE 5. Antioxidant enzymes of SOD (a), CAT (b), POD (c), and APX (d) activity in apple leaves. The data represent the average value \pm SE $(n=3)$. Different letters indicate significant differences as determined by Duncan's multiple range test at $P \leq 0.05$.
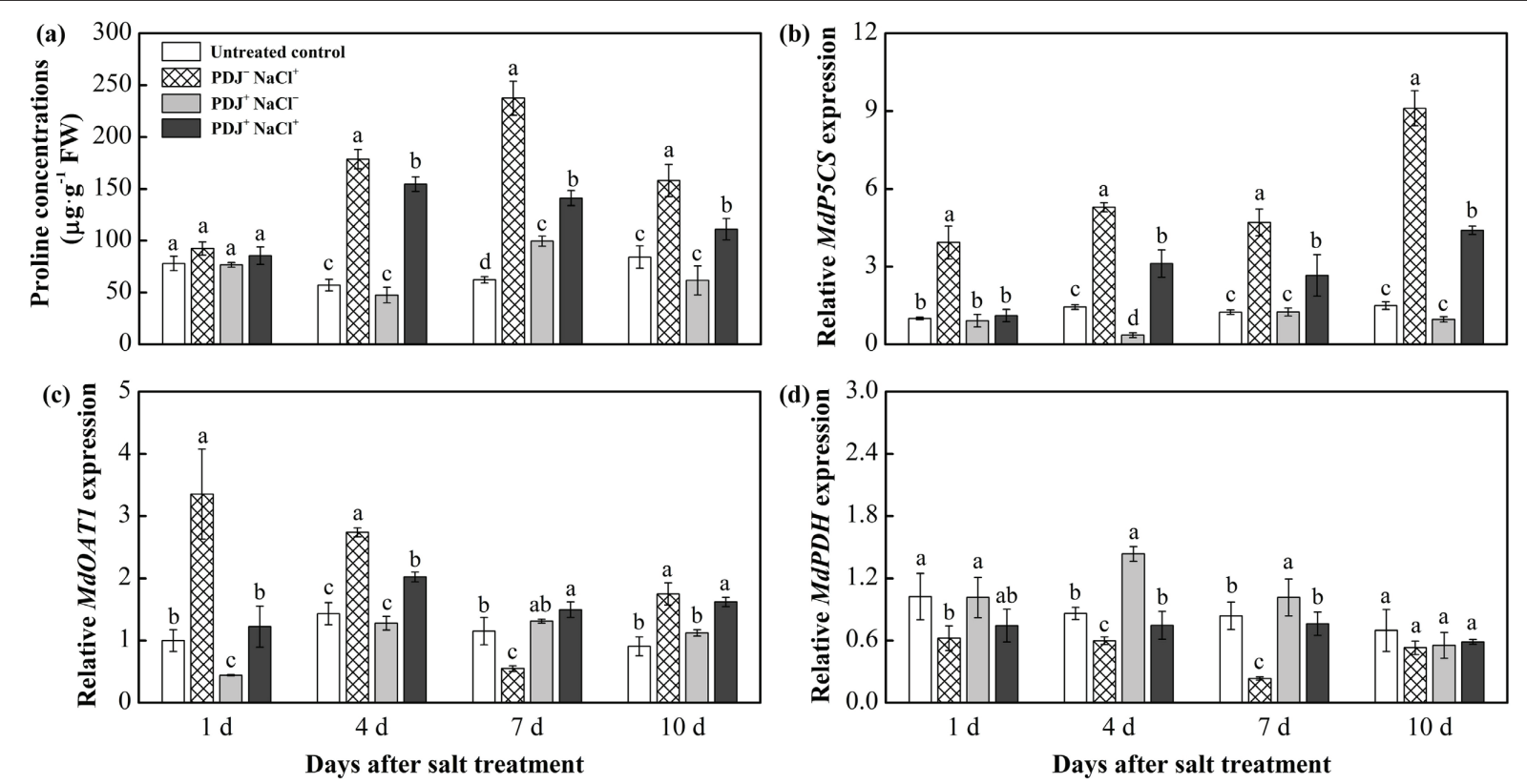

FiguRE 6. Proline concentrations (a) and gene expressions of MdP5CS (b), MdOAT1 (c), and MdPDH (d) in apple leaves under different treatments. The data represent the average value \pm SE $(n=3)$. Different letters indicate significant differences as determined by Duncan's multiple range test at $\mathrm{P} \leq 0.05$.

the JA and ABA response, hence modulating multiple defense systems to overcome the adverse impacts caused by salt.

$\mathrm{H}_{2} \mathrm{O}_{2}$ is an important signaling molecule that is involved in many metabolic processes, and its excessive generation frequently triggers oxidative stress, lipid peroxidation and MDA accumulation (Liu et al., 2020). In our study, the high concentrations of $\mathrm{H}_{2} \mathrm{O}_{2}$ and $\mathrm{MDA}$ in the $\mathrm{PDJ}-\mathrm{NaCl}^{+}$group suggested the occurrence of oxidative stress. In contrast, the lower level of $\mathrm{H}_{2} \mathrm{O}_{2}$ and MDA in the $\mathrm{PDJ}^{+} \mathrm{NaCl}^{+}$group implies a mitigation effect of PDJ application on oxidative injury caused by $\mathrm{NaCl}$ stress. This result may be associated with the higher SOD, POD, and CAT enzyme activities in the $\mathrm{PDJ}^{+} \mathrm{NaCl}^{+}$group. Shu et al. (2016) reported that the accumulation of endogenous ABA mediated $\mathrm{H}_{2} \mathrm{O}_{2}$ generation, which consequently induced the antioxidant defense systems and enhanced cucumber (Cucumis sativus L.) salt tolerance. The increase of these enzyme activities was essential for enhancing salt tolerance in wheat (Triticum aestivum L.) and grapes (Vitis vinifera L.) (Qiu et al., 2014; Haider et al., 2019). Our results were consistent with those of a previous report by Kondo et al. (2009), who found that exogenous application of PDJ enhanced the chilling tolerance of the fruits by increasing the radical scavenging ability. Additionally, Shan and Yang (2017) also found that exogenous JA induced other antioxidant metabolites such as ascorbic acid and glutathione synthesis with neutralized toxic effects of $\mathrm{NaCl}$ stress. Thus, the reduction of $\mathrm{H}_{2} \mathrm{O}_{2}$ and the enhancement of SOD, POD, and CAT enzyme activities in the $\mathrm{PDJ}^{+} \mathrm{NaCl}^{+}$group led to higher radical scavenging activity to minimize the oxidative injury caused by $\mathrm{NaCl}$ stress. 


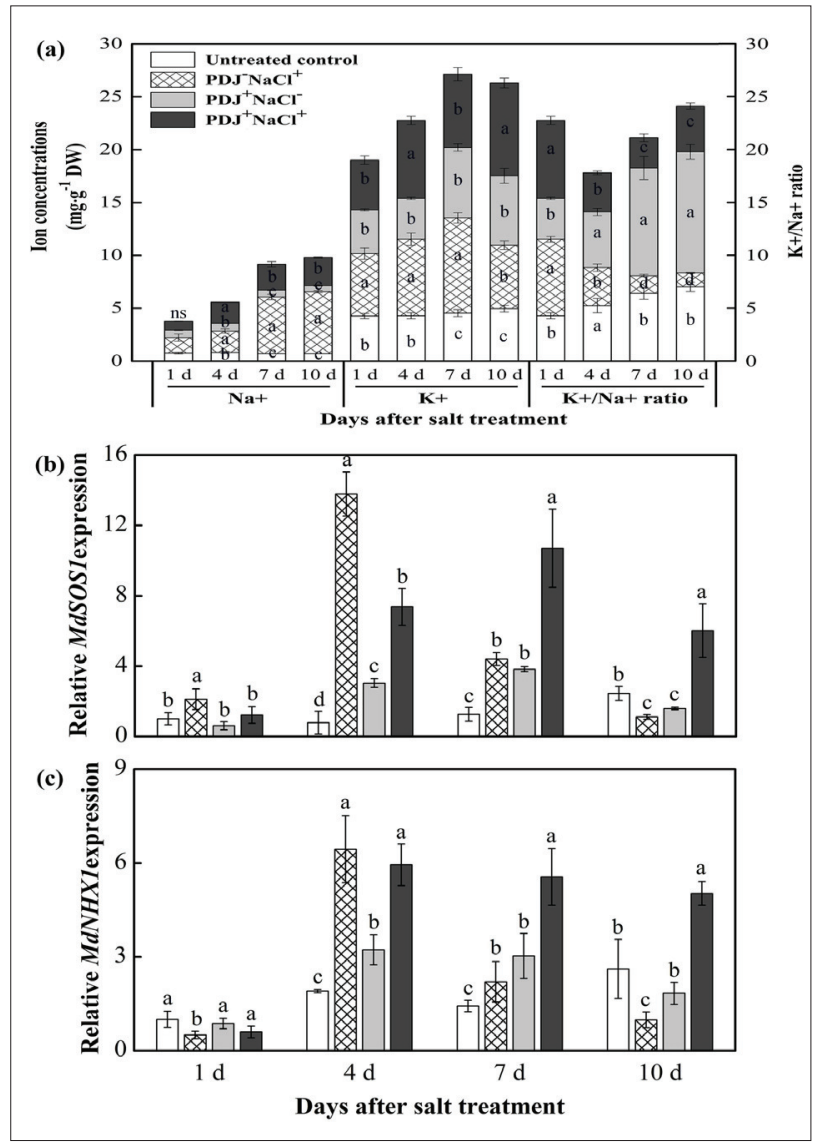

FIGURE 7. $\mathrm{Na}^{+}$and $\mathrm{K}^{+}$concentrations (a), MdSOS1 (b), and MdNHX1 (c) gene expressions in apple leaves under different treatments. The data represent the average value $\pm \operatorname{SE}(n=3)$. Different letters indicate significant differences as determined by Duncan's multiple range test at $\mathrm{P} \leq 0.05$.

Proline plays an essential role in stabilizing the membrane structure and enhancing the cell osmotic potential. It accumulates in many plant species in parallel with increased external salinity (Cao et al., 2020). In our study, the proline concentrations and the expressions of MdP5CS and MdOAT1 genes were significantly increased in both $\mathrm{NaCl}$ treated groups, with a reversed expression trend of the $M d P$ $\mathrm{DH}$ gene only in the PDJ-NaCl${ }^{+}$group. Cao et al. (2020) found that proline accumulation was attributed to a decrease expression of $O S P D H$ and an increase of the OSP5CS gene, which are regulated by ABA-dependent signals under $\mathrm{NaCl}$ stress. This result may support our result which showed that $\mathrm{NaCl}$ treatment induced proline and ABA accumulation. The lower proline concentrations in the $\mathrm{PDJ}{ }^{+} \mathrm{NaCl}^{+}$group may imply less injury to the seedlings due to $\mathrm{NaCl}$ stress.

It has been shown that plants increase $\mathrm{Na}^{+}$uptake and reduce $\mathrm{K}^{+}$uptake under salt stress (Garciadeblás et al., 2003). High $\mathrm{Na}^{+}$concentrations in plants retard the uptake of $\mathrm{K}^{+}$ions and accelerate their efflux, resulting in increased ion leakage and membrane lipid peroxidation in the leaves, as well as the occurrence of oxidative stress (Zhang et al., 2018). In our study, the $\mathrm{Na}^{+}$ion uptake in the PDJ- $\mathrm{NaCl}^{+}$group was increased significantly, while $\mathrm{K}^{+}$ion decreased, implying the occurrence of $\mathrm{Na}^{+}$toxicity. Nevertheless, the application of PDJ prior to $\mathrm{NaCl}$ stress caused lower $\mathrm{Na}^{+}$uptake and higher $\mathrm{K}^{+} /$ $\mathrm{Na}^{+}$ratio when compared with the $\mathrm{NaCl}$-only treated group. This result may show that PDJ regulates the absorption of $\mathrm{Na}^{+}$in plant tissues. Previous studies found that the overex- pression of $M d N H X 1$ or SOS1 genes decreased $\mathrm{Na}^{+}$efflux, enhancing salt resistance in apple and tobacco plant (Sun et al., 2017; Yue et al., 2012). The up-regulation of the MdSOS1 and $M d N H X 1$ genes in the $\mathrm{PDJ}^{+} \mathrm{NaCl}^{+}$group was concomitant with a reduced $\mathrm{Na}^{+}$concentration. This process was most likely regulated by endogenous ABA (Osakabe et al., 2014).

In conclusion, $\mathrm{PDJ}$ application prior to $\mathrm{NaCl}$ treatment could mitigate the $\mathrm{NaCl}$ stress by inducing the rapid accumulation of endogenous JA and ABA, enhancing antioxidant enzymes activities, regulating proline concentrations, reducing $\mathrm{Na}^{+}$uptake, and retarding the increase of MDA and ion leakage (Figure 8). Therefore, PDJ could be used to mitigate $\mathrm{NaCl}$ stress in fruit trees to stabilize yield and fruit quality.

\section{References}

Ahmad, P., Abdel Latef, A.A., Hashem, A., Abd Allah, E.F., Gucel, S., and Tran, L.-S.P. (2016). Nitric oxide mitigates salt stress by regulating levels of osmolytes and antioxidant enzymes in chickpea. Front. Plant Sci. 7, 347. https://doi.org/10.3389/fpls.2016.00347.

Annunziata, M.G., Ciarmiello, L.F., Woodrow, P., Maximova, E., Fuggi, A., and Carillo, P. (2017). Durum wheat roots adapt to salinity remodeling the cellular content of nitrogen metabolites and sucrose. Front. Plant Sci. 7, 2035. https://doi.org/10.3389/fpls.2016.02035.

Burton, K.W., King, J.B., and Morgan, E. (1986). Chlorophyll as an indicator of the upper critical tissue concentration of cadmium in plants. Water, Air, Soil Poll. 27(1-2) 147-154. https://doi. org/10.1007/BF00464777.

Cao, X., Wu, L., Wu, M., Zhu, C., Jin, Q., and Zhang, J. (2020). Abscisic acid mediated proline biosynthesis and antioxidant ability in roots of two different rice genotypes under hypoxic stress. BMC Plant Biol. 20,1-14. https://doi.org/10.1186/s12870-020-02414-3.

De Ollas, C., Hernando, B., Arbona, V., and Gómez-Cadenas, A. (2013). Jasmonic acid transient accumulation is needed for abscisic acid increase in citrus roots under drought stress conditions. Physiol. Plant. 147, 296-306. https://doi.org/10.1111/j.13993054.2012.01659.x.

Fang, Z., Bouwkamp, J.C., and Solomos, T. (1998). Chlorophyllase activities and chlorophyll degradation during leaf senescence in non-yellowing mutant and wild type of Phaseolus vulgaris L. J. Exp. Bot. 49, 503-510. https://doi.org/10.1093/jexbot/49.320.503.

Garciadeblás, B., Senn, M.E., Bañuelos, M.A., and RodríguezNavarro, A. (2003). Sodium transport and HKT transporters: The rice model. Plant J. 34, 788-801. https://doi.org/10.1046/j.1365313X.2003.01764.x.

Guan, C., Huang, Y.-H., Cen, H.-F., Cui, X., Tian, D.-Y., and Zhang, Y.-W. (2019). Overexpression of the Lolium perenne L. delta1-pyrroline 5-carboxylate synthase ( $L P P 5 C S$ ) gene results in morphological alterations and salinity tolerance in switchgrass (Panicum virgatum L.). PloS ONE 14, e0219669. https://doi.org/10.1371/journal. pone.0219669.

Haider, M.S., Jogaiah, S., Pervaiz, T., Yanxue, Z., Khan, N., and Fang, J. (2019). Physiological and transcriptional variations inducing complex adaptive mechanisms in grapevine by salt stress. Environm. Exp. Bot. 162, 455-467. https://doi.org/10.1016/j. envexpbot.2019.03.022.

He, J., Ren, Y., Chen, X., and Chen, H. (2014). Protective roles of nitric oxide on seed germination and seedling growth of rice (Oryza sativa L.) under cadmium stress. Ecotoxicol. Environm. Safety 108, 114119. https://doi.org/10.1016/j.ecoenv.2014.05.021.

Heath, R.L., and Packer, L. (1968). Photoperoxidation in isolated chloroplasts: I. Kinetics and stoichiometry of fatty acid peroxidation. Arch. Biochem. Biophysics 125, 189-198. https://doi. org/10.1016/0003-9861(68)90654-1. 


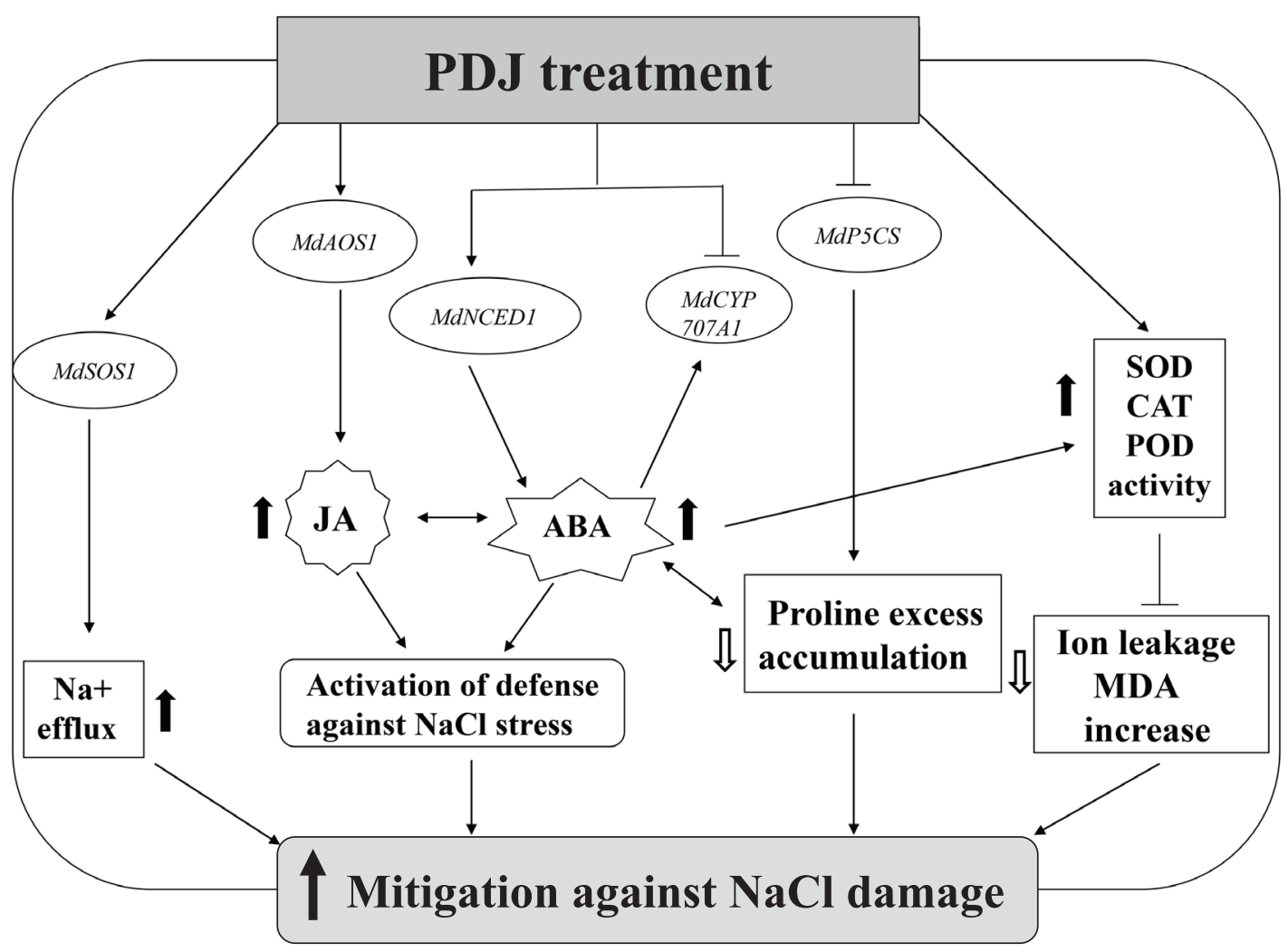

FIGURE 8. Schematic diagram of the regulation of NaCl tolerance in apple seedlings by PDJ treatment. Dark arrows indicate increases, and blank arrows indicate decreases.

Huang, Y., Jiao, Y., Xie, N., Guo, Y., Zhang, F., Xiang, Z., Wang, R., Wang, F., Gao, Q., and Tian, L. (2019). OsNCED5, a 9-cis-epoxycarotenoid dioxygenase gene, regulates salt and water stress tolerance and leaf senescence in rice. Plant Sci. 287,110188. https://doi.org/10.1016/j. plantsci.2019.110188.

Jambunathan, N. (2010). Determination and detection of reactive oxygen species (ROS), lipid peroxidation, and electrolyte leakage in plants. In Plant Stress Tolerance, R. Sunkar, ed. (Springer), p. 291297. https://doi.org/10.1007/978-1-60761-702-0_18.

Kim, S.K., Sohn, E.Y., and Joo, G.J. (2009). Influence of jasmonic acid on endogenous gibberellin and abscisic acid in salt-stressed chard plant. J. Environm. Biol. 30(3), 333-338.

Kondo, S. (2009). Roles of jasmonates in fruit ripening and environmental stress. Acta Hortic. 884, 711-716. https://doi. org/10.17660/ActaHortic.2010.884.96.

Kondo, S., Tomiyama, A., and Seto, H. (2000). Changes of endogenous jasmonic acid and methyl jasmonate in apples and sweet cherries during fruit development. J. Am. Soc. Hortic. Sci. 125, 282-287. https://doi.org/10.21273/JASHS.125.3.282.

Kondo, S., Sugaya, S., Sugawa, S., Ninomiya, M., Kittikorn, M., Okawa, K., Ohara, H., Ueno, K., Todoroki, Y., and Mizutani, M. (2012). Dehydration tolerance in apple seedlings is affected by an inhibitor of ABA 8'-hydroxylase CYP707A. J. Plant Physiol. 169, 234-241. https://doi.org/10.1016/j.jplph.2011.09.007.

Liu, S., Zhang, P., Li, C., and Xia, G. (2019). The moss jasmonate ZIMdomain protein PnJAZ1 confers salinity tolerance via crosstalk with the abscisic acid signalling pathway. Plant Sci. 280, 1-11. https://doi. org/10.1016/j.plantsci.2018.11.004.

Liu, T., Ye, X., Li, M., Li, J., Qi, H., and Hu, X. (2020). $\mathrm{H}_{2} \mathrm{O}_{2}$ and NO are involved in trehalose-regulated oxidative stress tolerance in coldstressed tomato plants. Environm. Experim. Bot. 171, 103961. https://doi.org/10.1016/j.envexpbot.2019.103961.
Osakabe, Y., Yamaguchi-Shinozaki, K., Shinozaki, K., and Tran, L.S.P. (2014). ABA control of plant macroelement membrane transport systems in response to water deficit and high salinity. New Phytol. 202, 35-49. https://doi.org/10.1111/nph.12613.

Pedranzani, H., Racagni, G., Alemano, S., Miersch, O., Ramírez, I., Peña-Cortés, H., Taleisnik, E., Machado-Domenech, E., and Abdala, G. (2003). Salt tolerant tomato plants show increased levels of jasmonic acid. Plant Growth Regul. 41, 149-158. https://doi. org/10.1023/A:1027311319940.

Qiu, Z., Guo, J., Zhu, A., Zhang, L., and Zhang, M. (2014). Exogenous jasmonic acid can enhance tolerance of wheat seedlings to salt stress. Ecotoxicol. Environm. Safety 104, 202-208 https://doi. org/10.1016/j.ecoenv.2014.03.014.

Reddy, P.S., Jogeswar, G., Rasineni, G.K., Maheswari, M., Reddy, A.R., Varshney, R.K., and Kishor, P.K. (2015). Proline over-accumulation alleviates salt stress and protects photosynthetic and antioxidant enzyme activities in transgenic sorghum [Sorghum bicolor (L.) Moench]. Plant Physiol. Biochem. 94, 104-113. https://doi. org/10.1016/j.plaphy.2015.05.014.

Rezai, S., Orojloo, M., Bidabadi, S.S., and Soleimanzadeh, M. (2013). Possible role of methyl jasmonate in protection to $\mathrm{NaCl}$-induced salt stress in pepper cv. 'Green Hashemi'. Int. J. Agric. Crop Sci. 6, 1235 .

Ruan, J., Zhou, Y., Zhou, M., Yan, J., Khurshid, M., Weng, W., Cheng, J., and Zhang, K. (2019). Jasmonic acid signaling pathway in plants. Int. J. Molec. Sci. 20, 2479. https://doi.org/10.3390/ijms20102479.

Sales, L., Ohara, H., Ohkawa, K., Saito, T., Todoroki, Y., Srilaong, V., and Kondo, S. (2017). Salt tolerance in apple seedlings is affected by an inhibitor of ABA 8'-hydroxylase CYP707A. J. Plant Growth Regul. 36, 643-650. https://doi.org/10.1007/s00344-017-9665-y.

Shan, C., and Yang, T. (2017). Nitric oxide acts downstream of hydrogen peroxide in the regulation of ascorbate and glutathione 
metabolism by jasmonic acid in Agropyron cristatum leaves. Biol. Plant. 61, 779-784. https://doi.org/10.1007/s10535-017-0708-9.

Shi, S., Wang, G., Wang, Y., Zhang, L., and Zhang, L. (2005). Protective effect of nitric oxide against oxidative stress under ultraviolet-B radiation. Nitric Oxide 13, 1-9. https://doi.org/10.1016/j. niox.2005.04.006.

Shu, S., Gao, P., Li, L., Yuan, Y., Sun, J., and Guo, S. (2016). Abscisic acid-induced $\mathrm{H}_{2} \mathrm{O}_{2}$ accumulation enhances antioxidant capacity in pumpkin-grafted cucumber leaves under $\mathrm{Ca}\left(\mathrm{NO}_{3}\right)_{2}$ stress. Front. Plant Sci. 7, 1489. https://doi.org/10.3389/fpls.2016.01489.

Suktawee, S., Shishido, M., Wang, S., Saito, T., Okawa, K., Ohara, H., Nimitkeatkai, H., Ikeura, H., and Kondo, S. (2019). n-Propyl dihydrojasmonates influence ethylene signal transduction in infected apple fruit by Botrytis cinerea. Hortic. J. 88, 41-49 https:// doi.org/10.2503/hortj.UTD-001.

Sun, M.H., Ma, Q.J., and Liu, X. (2017). Molecular cloning and functional characterization of MdNHX1 reveals its involvement in salt tolerance in apple calli and Arabidopsis. Sci. Hortic. 215, 126133. https://doi.org/10.1016/j.scienta.2016.11.031.

Waśkiewicz, A., Beszterda, M., and Goliński, P. (2013). ABA: role in plant signaling under salt stress. In Salt Stress in Plants, P. Ahmad, M.M. Azooz, and M.N.V. Prasad, eds. (Springer), p. 175-196. https:// doi.org/10.1007/978-1-4614-6108-1_8.

Yamaguchi, T., Hamamoto, S., and Uozumi, N. (2013). Sodium transport system in plant cells. Front. Plant Sci. 4, 410. https://doi. org/10.3389/fpls.2013.00410.

Yang, J., Duan, G., Li, C., Liu, L., Han, G., Zhang, Y., and Wang, C. (2019). The crosstalks between jasmonic acid and other plant hormone signaling highlight the involvement of jasmonic acid as a core component in plant response to biotic and abiotic stresses. Front. Plant Sci. 10. https://doi.org/10.3389/fpls.2019.01349.
Yu, L., Liu, J., Zhuang, Z., Yang, L., Zhang, R., Ye, X., and Cheng, J. (2007). Quantitative analysis of real-time PCR expression production by REST and 2-(( $\Delta \Delta \mathrm{CT}))$. J. Trop. Med. 10, 956-958.

Yue, Y., Zhang, M., and Zhang, J. (2012). SOS1 gene overexpression increased salt tolerance in transgenic tobacco by maintaining a higher K+/Na+ ratio. J. Plant Physiol. 169(3), 255-261. https://doi. org/10.1016/j.jplph.2011.10.007.

Zhang, Y., Fang, J., Wu, X., and Dong, L. (2018). $\mathrm{Na}^{+} / \mathrm{K}^{+}$balance and transport regulatory mechanisms in weedy and cultivated rice (Oryza sativa L.) under salt stress. BMC Plant Biol. 18, 375. https:// doi.org/10.1186/s12870-018-1586-9.

Received: Sep. 29, 2020

Accepted: Dec. 16, 2020

Addresses of authors:

Liwei Wang ${ }^{1}$, Shanshan Wang ${ }^{1}$, Hiroyuki Tomiyama ${ }^{1}$,

Peter Opio ${ }^{1}$, Hitoshi Ohara ${ }^{2}$, Katsuya Ohkawa ${ }^{1}$,

Takanori Saito ${ }^{1}$ and Satoru Kondo ${ }^{1, *}$

${ }^{1}$ Graduate School of Horticulture, Chiba University, Matsudo 271-8510, Japan

${ }^{2}$ Center for Environment, Health and Field Sciences,

Chiba University, Kashiwa 277-0882, Japan

* Corresponding author;

E-mail: s-kondo@faculty.chiba-u.jp

Tel./Fax: +(81)-47-308-8800

\section{SUPPLEMENTAL INFORMATION}

Supplemental Table S1. Primers used for qRT-PCR analysis in this study.

\begin{tabular}{|c|c|c|}
\hline Gene & Forward/reverse primer $\left(5^{\prime}-3\right)$ & Accession No. \\
\hline \multirow[t]{2}{*}{ MdNCED1 } & (F) TACTACTACTACTACTACTACA & XM_009356579 \\
\hline & (R) GAAGGTTGTTGATAGGAA & \\
\hline \multirow[t]{2}{*}{ MdCYP707A1 } & (F) ACCGAGGAGATTACCATA & XM_008358695 \\
\hline & (R) CTTCAATGCCAGGAACTA & \\
\hline \multirow[t]{2}{*}{ MdAOS1 } & (F) GAACCTGTTATCCACTCT & XM_008366758.3 \\
\hline & (R) GGAAGACTCGTAGAAGAA & \\
\hline \multirow[t]{2}{*}{ MdJAR } & (F) CTGCCTTCAATCAACATT & XM_008377840.2 \\
\hline & (R) AATCAACAACTTCCAACTT & \\
\hline \multirow[t]{2}{*}{ MDJAZ2 } & (F) АTTCTTGTCTTCCGTCTCT & NM_001328912.1 \\
\hline & (R) ACCTTGCCTATCGTGATT & \\
\hline \multirow[t]{2}{*}{ MdP5CS } & (F) TTATCGGACTTGTGAATA & XM_008389606.3 \\
\hline & (R) ACAGGTATCTTAGTTGAC & \\
\hline \multirow[t]{2}{*}{ MdOAT1 } & (F) CGAGTATCTAACAAGCAT & XM_017327930.2 \\
\hline & (R) ACACGAGACAATAATAGC & \\
\hline \multirow[t]{2}{*}{ MdPDH } & (F) AAGCCAATGTGCCTCTAT & XM_008359589.3 \\
\hline & (R) AGGAGTAGGTCAAGTAATCG & \\
\hline \multirow[t]{2}{*}{ MdSOS1 } & (F) ACCTGCTGACTGGCCCT & XM_008391743.1 \\
\hline & (R) ATGTTCCAGTAAGCAGCTTGG & \\
\hline \multirow[t]{2}{*}{$M d N H X 1$} & (F) GGTGTTCGGATTGATGAC & NM_001328858.1 \\
\hline & (R) AGTGGTTGGTTCTGATGA & \\
\hline \multirow[t]{2}{*}{ Ubiquitin11 } & (F) TCGCTGGAAAGCAGCTCGAAGA & XM_008360582.2 \\
\hline & (R) GCTTTCCGGCAAAGATCAGACG & \\
\hline
\end{tabular}

